\title{
Pb Isotopes Study in Recent Sediments from Paraty Bay (Rio de Janeiro, Brazil): Antropogenic Versus Oceanic Signatures
}

\author{
M. C. Geraldes ${ }^{1}$, S. D. Pereira' ${ }^{2}$ H. H. Villena' ${ }^{2}$, F. W. e Herms ${ }^{2}$ \\ ${ }^{1}$ Faculty of Geology-UERJ, São Francisco Xavier, Maracanã, Rio de Janeiro, Brazil \\ ${ }^{2}$ Faculty of Oceanografy-UERJ, Rua São Francisco Xavier, Maracanã, Rio de Janeiro, Brazil \\ Email: geraldes@uerj.br, silviadp@uerj.br, heliovillena@gmail.com, fredwh@uerj.br
}

Received 19 May 2015; accepted 11 July 2015; published 16 July 2015

Copyright (c) 2015 by authors and Scientific Research Publishing Inc.

This work is licensed under the Creative Commons Attribution International License (CC BY). http://creativecommons.org/licenses/by/4.0/

(c) (i) Open Access

\section{Abstract}

We carried out $\mathrm{Pb}$ isotopes studies in sediments from Paraty Bay located in the SE area of the Rio de Janeiro State to discriminate the signature of metal contamination from domestic sewage, industries, shipyards and geogenic sources. The studied samples have been chosen in two sectors of the Bay, including the Paraty area and Juatinga Bay. Sample preparation procedures included: 1) drying and granulometric separations (200 mesh); 2) weighting; 3) complete dissolution and 4) $\mathrm{Pb}$ isotope analysis obtained by MC-ICP-MS (ratios ${ }^{208} \mathrm{~Pb} /{ }^{204} \mathrm{~Pb},{ }^{207} \mathrm{~Pb} /{ }^{204} \mathrm{~Pb},{ }^{206} \mathrm{~Pb} /{ }^{204} \mathrm{~Pb}$ ). Preliminary results when plotted in the ${ }^{207} \mathrm{~Pb} /{ }^{204} \mathrm{~Pb}$ versus ${ }^{208} \mathrm{~Pb} /{ }^{204} \mathrm{~Pb}$ and ${ }^{207} \mathrm{~Pb} /{ }^{206} \mathrm{~Pb}$ versus ${ }^{206} \mathrm{~Pb} /{ }^{204} \mathrm{~Pb}$ diagrams showed three groups of signatures. The first group (samples PY-01, PY-03 PY-106 and $\mathrm{PY}-127$ ) presented ${ }^{207} \mathrm{~Pb} /{ }^{206} \mathrm{~Pb}$ values in the range from 1.191 to 1.209 . The isotope values may be interpreted as contribution of a pollutant sources of $\mathrm{Pb}$ not yet identified. The second group (PY-11, PY-13, PY-21, PY-22, PY-46, PY-51, PY-109 and PY-111) showed ${ }^{207} \mathrm{~Pb} /{ }^{206} \mathrm{~Pb}$ values in the range from 1.188 to 1.222 . The last group (samples $P Y-123$ and $P Y-135$ ) presented higher ${ }^{207} \mathrm{~Pb} /$ ${ }^{206} \mathrm{~Pb}$ values from 1.321 to 1.322 and probably represented oceanic signature. The $\mathrm{Pb}$ isotope data of the second group may be interpreted as the result of oceanic water and pollutant sources mixture from the continent. According to the literature the anomalous $\mathrm{Pb}$ signature is similar to anthropogenic source. The $\mathrm{Pb}$ isotope results here reported are coherent with the reported data from the continent area. We may conclude that significant isotopic differences in $\mathrm{Pb}$ signatures are consequence of anthropogenic $\mathrm{Pb}$ isotope signature. In this way, $\mathrm{Pb}$ isotope is an important tool to trace the changing sources of pollutant $\mathrm{Pb}$ (and other metals) in ocean environment.

\section{Keywords}

Pb Isotopes, Paraty Bay, Metal Pollutants

How to cite this paper: Geraldes, M.C., Pereira, S.D., Villena, H.H. and e Herms, F.W. (2015) Pb Isotopes Study in Recent Sediments from Paraty Bay (Rio de Janeiro, Brazil): Antropogenic Versus Oceanic Signatures. International Journal of Geosciences, 6, 645-655. http://dx.doi.org/10.4236/ijg.2015.67052 


\section{Introduction}

Industrial emissions and lead addition in the gasoline are responsible for the great amount of lead in the environment. The variety of used lead ores in the industrial activities has introduced this metal that presents different abundances between its isotopes. This abundance of isotopes defines signatures allowing identifying industrial sources that use ores of different origins, allowing the use of the isotopic ratios as an efficient tracer of natural or polluting sources in the environment. Studies on the sources of contaminant metals, its dynamic of transport as well as its destination can provide one better understanding on the impact in the global biogeochemical cycle. In the south hemisphere the information regarding the isotopic signatures of the lead are scarce, having as pioneering work developed by [1].

This study was focused in the Paraty Bay (Figure 1), limited in the northeast for the Serra do Mar, in the southeast for the Maciço de Cunha and to the south for the Maciço de Trindade. These mountains comprise high areas (up to $1.4 \mathrm{~km}$ ) formed by Neproterozoic orogenies (Ribeira Belt rocks). The study area is located in most important geoeconomic area of Brazil, which encloses the cities of Rio de Janeiro, São Paulo, Belo Horizonte and Vitória, being considered a potentially catalytic area of development blunting as one of the industrial and tourist polar regions of the State of Rio de Janeiro.

The antropic activity of this region is responsible for launching of some potentially toxic substances in the tributaries that empty in the Bay, being distinguished the heavy metals. They have the circulation limited and are carried to the estuarine zones. Among the activities distinguished mainly the marinas, responsible for fuel spilling.

The regional geology of the area of the Paraty Bay includes units of the Pre-Cambrian basement, Cretaceous alkaline bodies and Quaternary plains. The rocks of the basement are represented by charnockite gneisses and intercalated granites of maphic rocks probably of Neoproterozoic age. Finally the Quaternary sediments include coastal plains enclosing fluvial sediments, tide canals and mangrove. Geomorphologic features of the region of the Paraty Bay suggest close relation with the directions of the structures observed in the Precambrian rocks, but also younger generated during events of rifting and opening of the Atlantic Ocean. The sediments present arrangement that indicates the alignment to brittle Mesozoic structures that must have guided the evolution of the relief in the region. The Quaternary sedimentary sequences present continuity in the direction of the continental platform of the Santos Basin, where other older sedimentary sequences occur (Paleogen and Cretaceous) included in the rift transitional phases and marine (transgressive and regressive) of the continental margin.

The knowledge of the ecosystem of the region of the Paraty Bay, based on a detailed knowledge of the sea circulation, of the transport and deposition of sediments, is of great importance for the planning of a sustainable development of the resources of the region, as well as of mitigation of the observed impacted environment.

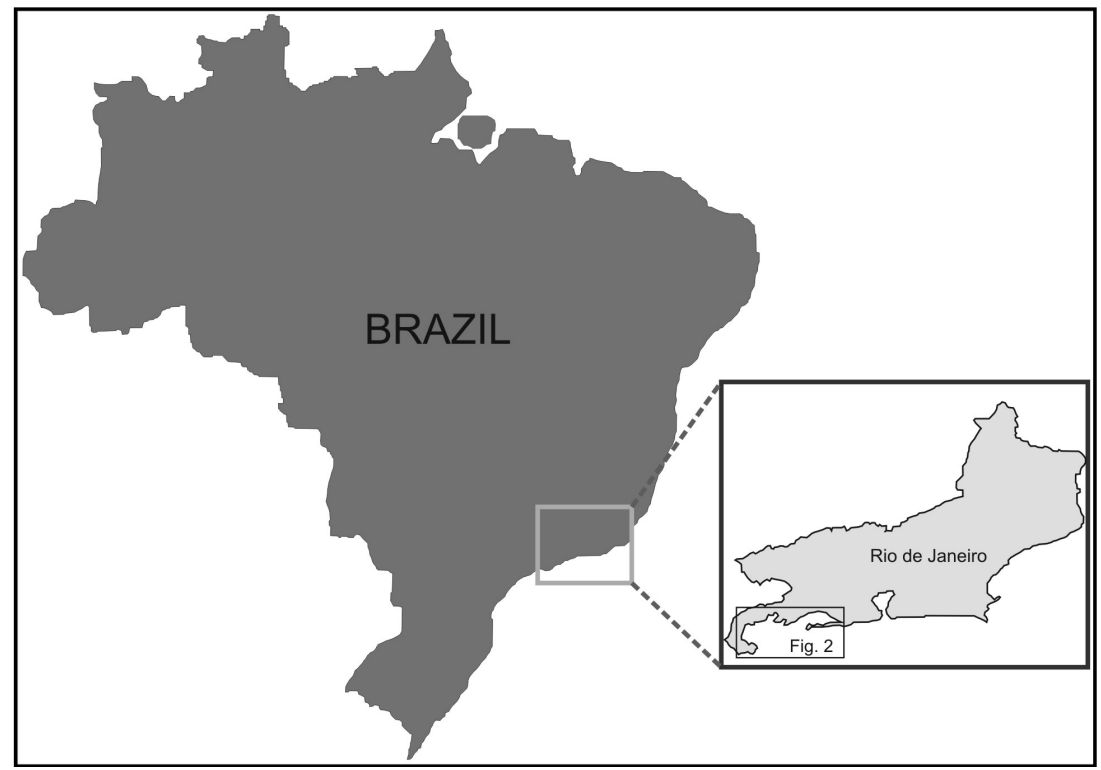

Figure 1. Location of studied area in Rio de Janeiro state. 


\section{Metal Contamination and $\mathrm{Pb}$ Isotope Signature}

In such a way, the validation of the characteristics of the contaminations in heavy metals and its possible sources present high relevance for the characterization of the exposition human being resulted of the process of industrialization and activities of tourism. The methodology had as focus the sediments and its isotopic signatures of lead.

The heavy metals can be highly toxic and the increase of its concentration in the atmosphere and hydrosphere can characterize a local pollution with high risk for the human and animal health [2]. In industrial and port areas, as it is the case in the Paraty Bay, innumerable are the anthropogenic sources that can liberate pollutants for the environment, being great the difficulty of distinguishing these sources as well as quantifying its partial contributions.

Secular and geographic modifications in the isotopic compositions of $\mathrm{Pb}$ can supply evidences to the presence of anthropogenic $\mathrm{Pb}$ compared with data of concentration of this element [3] [4]. The advantage of the $\mathrm{Pb}$ isotopic investigation relative to the quantitative studies is due the possibility of distinction of the signatures of anthropogenic and the natural $\mathrm{Pb}$ in a specific region [5]. This distinction, in turn, elapses of the maintenance of the original signature of the mineral deposit supplying of $\mathrm{Pb}$ that becomes a pollutant agent through the antropic action [6]. Research carried in the industrialized countries has shown that the characterization of each source can be made with precision, using the isotopic compositions of $\mathrm{Pb}$ of each of the probable sources of this element [7].

The general objective of this work was the characterization of the sedimentary dynamics and the antropic contributions in the marine sediments (Figure 2) based on the application of environmental geochemistry and indication of the pollutants. Thus, this contribution intends the better characterization of the Pleistocene-Holocenic sedimentary deposits, to investigate the connection between the sedimentary evolution of the half-closed environment of Paraty Bay and its relation with environments and the evolution of the sedimentary system of continental shelf around State of Rio de Janeiro.

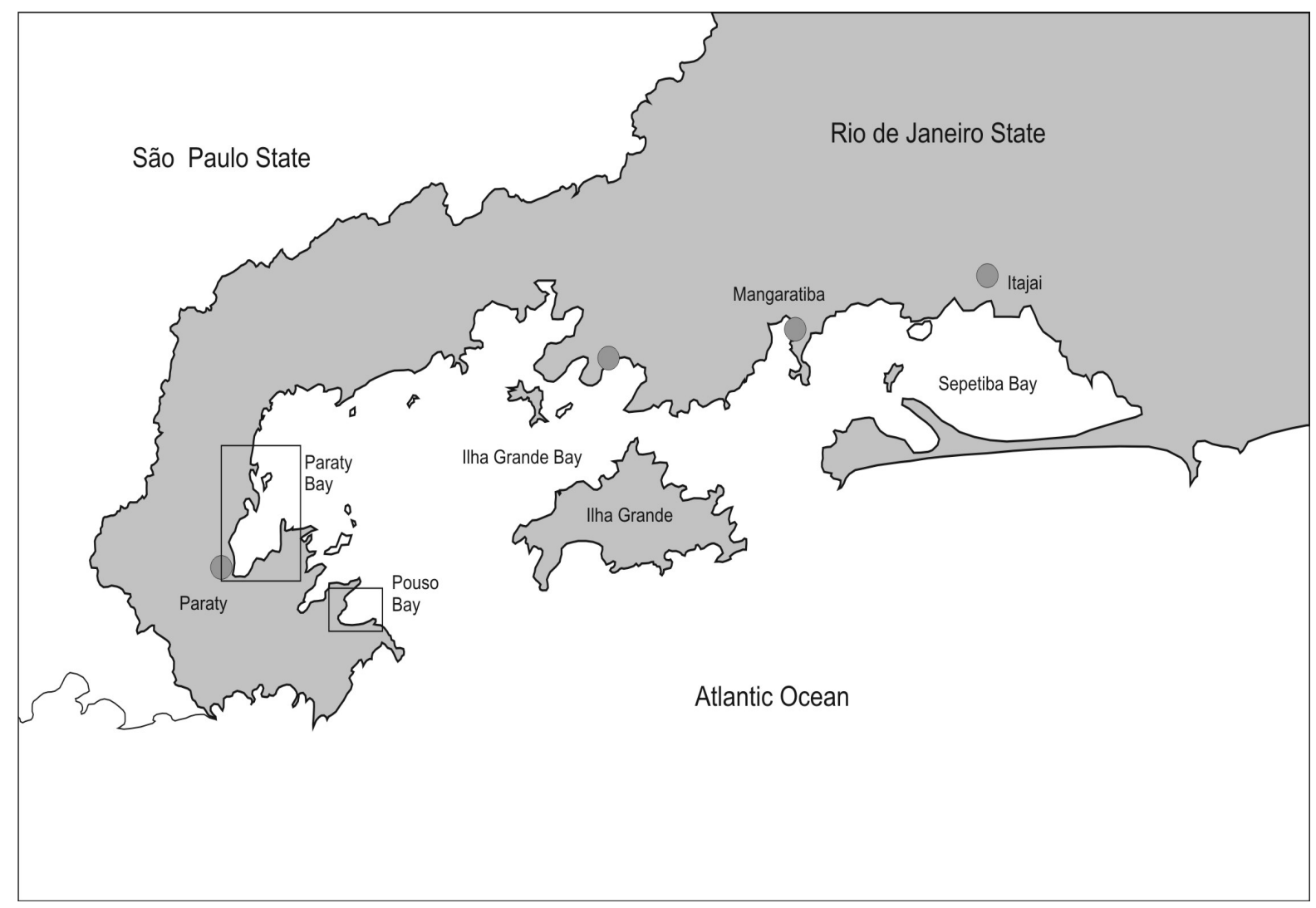

Figure 2. Location of the Paraty region in SE Brazil. 


\section{Procedures}

The 15 samples had been collected using Van Veen during 3 days of work from March to September of 2008. After they had been carried to the Geologic Laboratory of Sample Preparation (LGPA-UERJ) for the procedures of grain sized separation (fractions lesser than 200 mesh). The chemical preparation consisted in weighing of 0.1 $\mathrm{g}$ of sediment, total dissolution in acid way $\left(\mathrm{HNO}_{3}+\mathrm{HF}\right)$, and posterior reading in the spectrometer of mass (ICP-MS) in ACTLABS Laboratory in Canada. The sample preparation was carried through in the following stages:

1) First the samples had been removed of the plastic bags and placed in aluminum containers to avoid contamination and, after that, placed in box of light until the total drying. In some samples having large amounts of clay after the drying was necessary to make the disaggregation of the material.

2) The following step was to sieving the samples in fractions of $2.0 \mathrm{~mm}$ (10 mesh), $1.41 \mathrm{~mm}$ (14 mesh), 0.50 mm (35 mesh), $0.35 \mathrm{~mm}$ (45 mesh), $0.17 \mathrm{~mm}$ (80 mesh), $0.12 \mathrm{~mm}$ (120 mesh), $<0.12 \mathrm{~mm}$.

3) After the total weighing of the material accumulated in each sieve a fraction of 2.0 grams of each fraction of the material had been separate for analysis. This preparation did not present serious problems of contamination due to high concentration of $\mathrm{Pb}$ in the samples.

4) The $2.0 \mathrm{~g}$ fraction of each sample had been placed in becker with $8 \mathrm{ml}$ of $\mathrm{H}_{2} \mathrm{O}_{2}$ for elimination of the organic matter. After this they had been placed in the stove until the complete drying of the material.

5) After the drying the material was weighed again and carried to the mass spectrometer laboratory. Chemical attack for dissolution of the samples procedures had the objective to dissolve the sediment for the ionization of metals. For this, the $\mathrm{HNO}_{3}$ and $\mathrm{HF}$ acids, both in the concentration of $6 \mathrm{~N}$ had been used.

6) Spectrometry of Mass Analysis. The isotopic analyses had been carried through in spectrometer of mass with induced plasma (HR-ICP-MS). This technique presents the advantage of eliminate the phase of concentration of $\mathrm{Pb}$ by ionic exchange column and also for not using tracers. For such, standards for correction of isotopic fractionation are used.

7) $\mathrm{The} \mathrm{Pb}$ isotope data used in geochronological studies have their values expressed in relation to the isotope ${ }^{204} \mathrm{~Pb}$, that is, ${ }^{208} \mathrm{~Pb} /{ }^{204} \mathrm{~Pb},{ }^{207} \mathrm{~Pb} /{ }^{204} \mathrm{~Pb}$ and ${ }^{206} \mathrm{~Pb} /{ }^{204} \mathrm{~Pb}$ ratios. However, in environmental studies, since the first works published in the end of the decade of 1960, the use of the ratios between three radiogenic isotopes was preferred $\left({ }^{208} \mathrm{~Pb},{ }^{207} \mathrm{~Pb}\right.$ and $\left.{ }^{206} \mathrm{~Pb}\right)$. This preference is justified because these isotopes occur in larger abundance than the ${ }^{204} \mathrm{~Pb}$ isotope, and consequently, their signals obtained in the mass spectrometer are steadier and present values closely between themselves. In this way the ratios between them present more accurate values, favoring the data interpretation. Another advantage of using the ratios ${ }^{208} \mathrm{~Pb} /{ }^{207} \mathrm{~Pb}$ or ${ }^{206} \mathrm{~Pb} /{ }^{207} \mathrm{~Pb}$ is to prevent the corrections of interferences of ${ }^{204} \mathrm{~Pb}$, as mercury. In such a way diagrams as ${ }^{208} \mathrm{~Pb} /{ }^{207} \mathrm{~Pb}$ versus ${ }^{206} \mathrm{~Pb} /{ }^{207} \mathrm{~Pb}$ had been created making possible the identification of the isotopic signatures of the varied anthropogenic and natural sources.

\section{Results}

The sediments of the Paraty Bay had been investigated with the aim to characterize the isotopic signatures of $\mathrm{Pb}$ to identify the antropic and natural contributions of metals in the marine region. The area presents potentially polluting activities of the ocean as domestic sewer, industrial and port activities. The area presents two small bays represented for Paraty and Pouso where the deep sediments had been sampled (by Van Veen), being 9 places in the first area (PY-01, PY-03, PY-11, PY-13, PY-21, PY-22, PY-35, PY-46 and PY-51). Samples had been collected in Paraty Bay as shoed in Figure 3. In the Pouso Bay, 6 samples had been collected (PY-106, PY-109, PY-111, PY-123, PY-127 and PY-135), with localization presented in Figure 4. In Table 1 the values of the isotopic ratios of $\mathrm{Pb}$ are presented.

The results when plotted in the diagram ${ }^{207} \mathrm{~Pb} /{ }^{204} \mathrm{~Pb}$ versus ${ }^{208} \mathrm{~Pb} /{ }^{204} \mathrm{~Pb}$ (Figure 5) and the diagram ${ }^{207} \mathrm{~Pb} /{ }^{206} \mathrm{~Pb}$ versus ${ }^{206} \mathrm{~Pb} /{ }^{204} \mathrm{~Pb}$ (Figure 6) can tentatively be grouped in three sets. The first group (samples PY-01, PY-03 PY-106 and PY-127) had presented values of ${ }^{207} \mathrm{~Pb} /{ }^{204} \mathrm{~Pb}$ between 1.191 and 1.209 . This group can be interpreted as an anthropogenic source not yet identified and is comprised by samples next to the continent.

The second group (samples PY-11, PY-13, PY-21, PY-22, PY-46, PY-51, PY-109 and PY-111) showed values of ${ }^{207} \mathrm{~Pb} /{ }^{204} \mathrm{~Pb}$ between 1.188 and 1.222 . The last group (samples PY-123 and PY-135) presented higher values of ${ }^{207} \mathrm{~Pb} /{ }^{204} \mathrm{~Pb}$ reaching 1.321 the 1.323 and probably it represents a sea signature as the samples were collected in the sites more moved away from the coast). The isotopic signature of the second group can be interpreted as a 


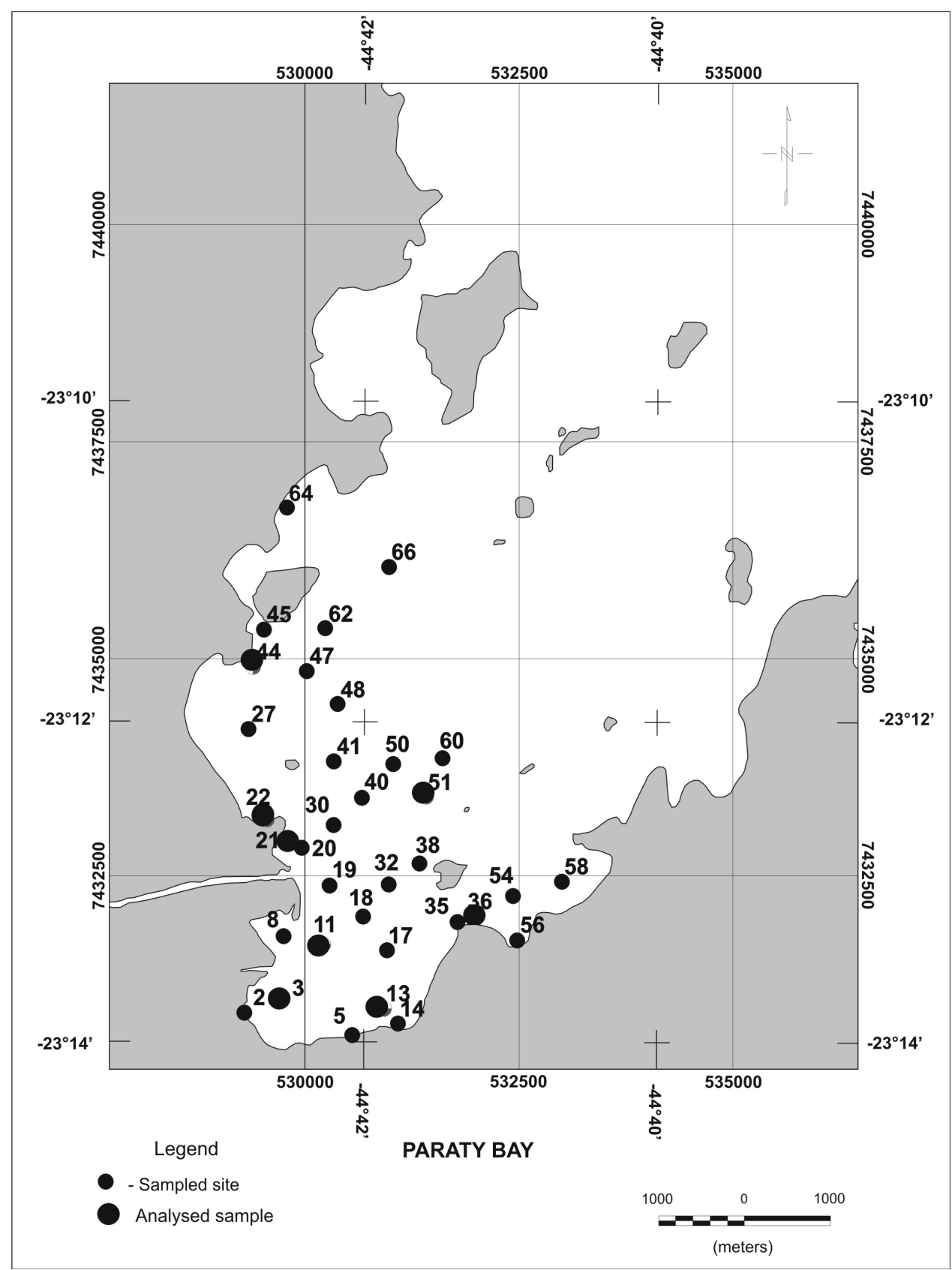

Figure 3. Points of samples collected in the Paraty Bay.

mixture between groups one and three.

The values of isotopes of the lead indicate different signatures and can be interpreted as contamination for two different sources of pollution, being able to define possible end members. The end member $\mathrm{A}$ is represented by the samples next to the continent and the end member $B$ is represented by the samples next to the ocean not contaminated. The remaining samples may be interpreted as intermediate values and as mixture between the two end members.

\section{Discussion and Conclusions}

The ratios ${ }^{206} \mathrm{~Pb} /{ }^{207} \mathrm{~Pb}$ for the Paraty Bay had shown a variation between 1.180 and 1.202 and can be compared to reported anthropogenic signatures in other studies in Brazil. The isotopic signatures of the Pouso Bay indicate 


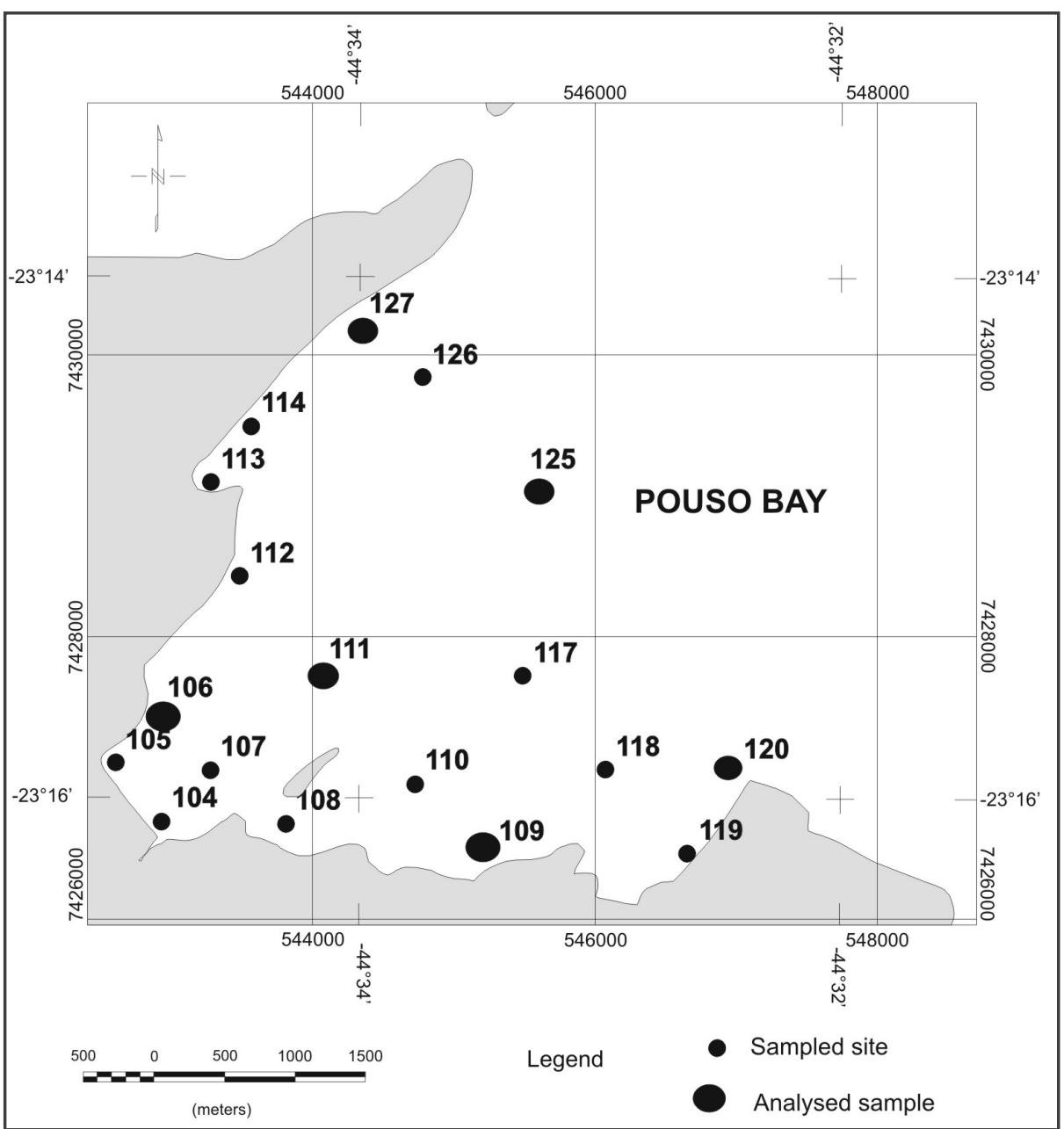

Figure 4. Points of samples collected in the Pouso Bay.

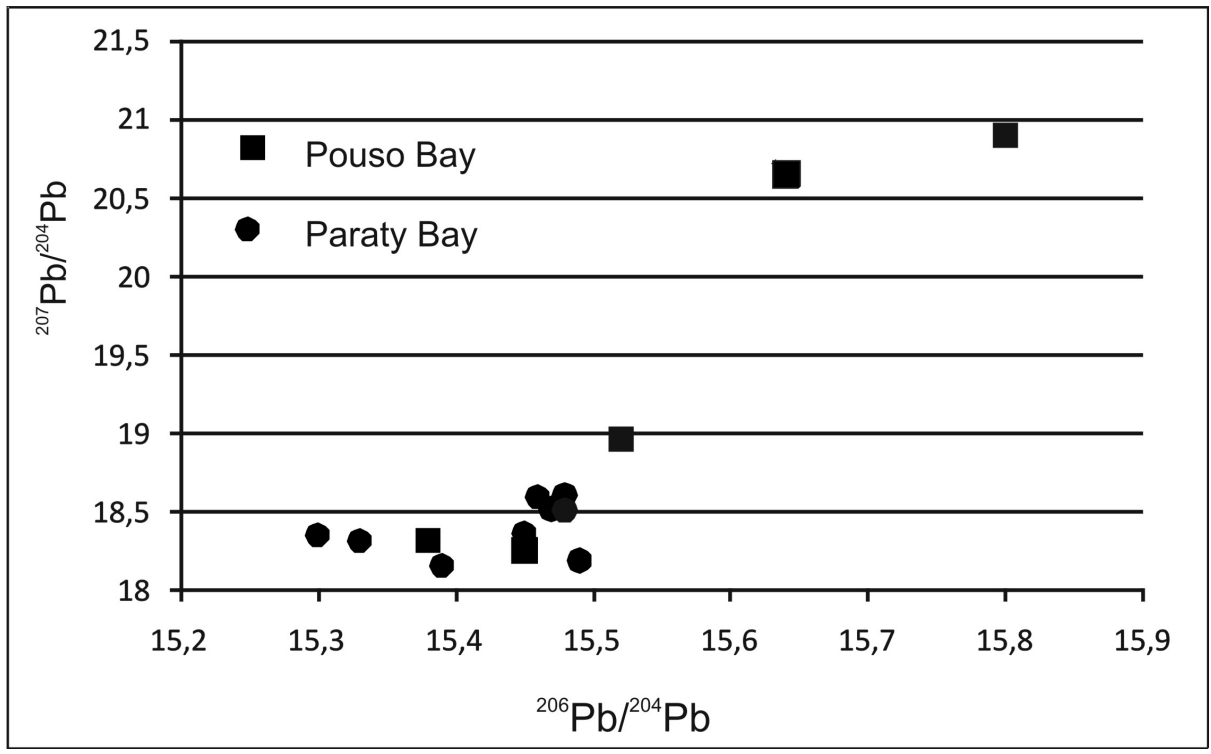

Figure 5. Diagram ${ }^{207} \mathrm{~Pb} /{ }^{204} \mathrm{~Pb}$ versus ${ }^{208} \mathrm{~Pb} /{ }^{204} \mathrm{~Pb}$ for the samples of the Paraty Bay and the Pouso Bay. 


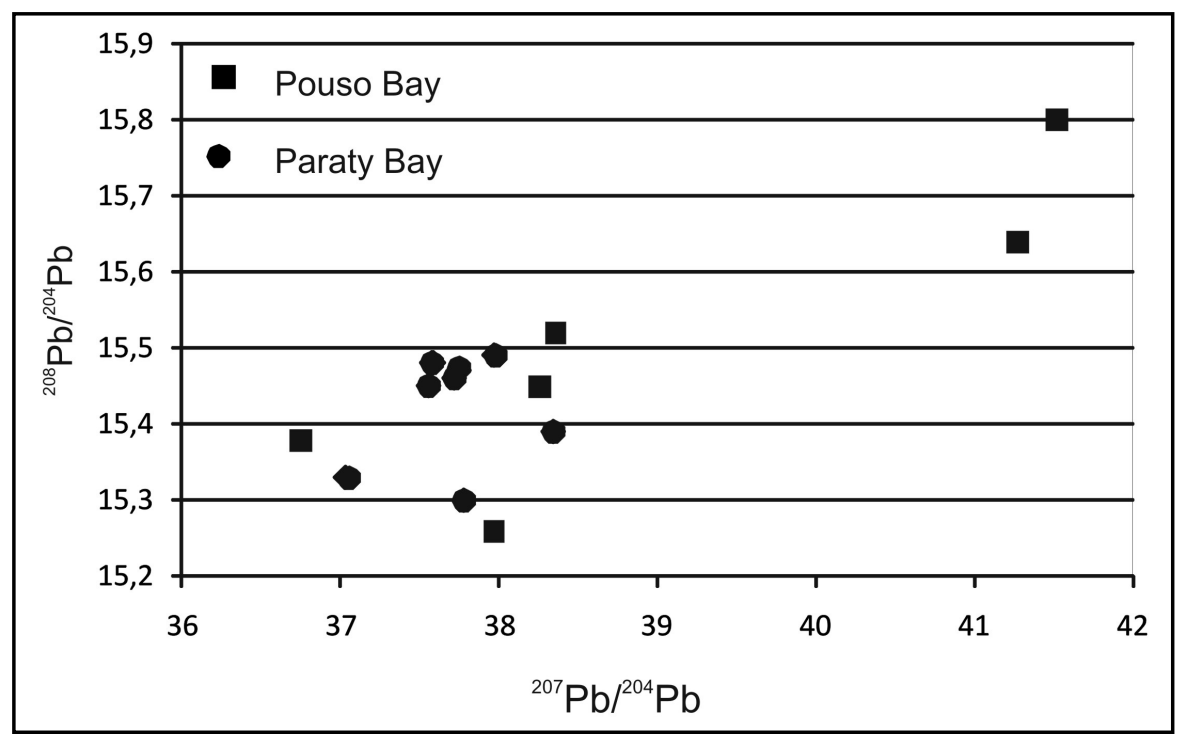

Figure 6. Diagram ${ }^{207} \mathrm{~Pb} /{ }^{206} \mathrm{~Pb}$ versus ${ }^{206} \mathrm{~Pb} /{ }^{204} \mathrm{~Pb}$ for the samples of the Paraty Bay and the Pouso Bay.

Table 1. Analytical results of isotopes of $\mathrm{Pb}$.

\begin{tabular}{|c|c|c|c|c|}
\hline Sample & ${ }^{208} \mathrm{~Pb} /{ }^{204} \mathrm{~Pb}$ & ${ }^{207} \mathrm{~Pb} /{ }^{204} \mathrm{~Pb}$ & ${ }^{206} \mathrm{~Pb} /{ }^{204} \mathrm{~Pb}$ & ${ }^{206} \mathrm{~Pb} /{ }^{207} \mathrm{~Pb}$ \\
\hline PY-01 & 37.04 & 15.33 & 18.32 & 1.195 \\
\hline PY-03 & 37.78 & 15.3 & 18.35 & 1.199 \\
\hline PY-11 & 38.34 & 15.39 & 18.16 & 1.180 \\
\hline PY-13 & 37.72 & 15.46 & 18.6 & 1.203 \\
\hline PY-21 & 37.97 & 15.49 & 18.19 & 1.174 \\
\hline PY-22 & 37.56 & 15.45 & 18.37 & 1.189 \\
\hline PY-35 & 37.58 & 15.48 & 18.61 & 1.202 \\
\hline PY-46 & 37.75 & 15.47 & 18.52 & 1.197 \\
\hline PY-51 & 37.59 & 15.48 & 18.51 & 1.196 \\
\hline PY-106 & 37.97 & 15.26 & 18.45 & 1.209 \\
\hline PY-109 & 38.26 & 15.45 & 18.35 & 1.188 \\
\hline PY-111 & 38.36 & 15.52 & 18.96 & 1.222 \\
\hline PY-123 & 41.27 & 15.64 & 20.66 & 1.321 \\
\hline PY-127 & 36.75 & 15.38 & 18.32 & 1.191 \\
\hline PY-135 & 41.52 & 15.8 & 20.9 & 1.323 \\
\hline
\end{tabular}

two signatures, one closely to the continent and can be interpreted as of antropic origin, with values of ${ }^{207} \mathrm{~Pb} /$ ${ }^{206} \mathrm{~Pb}$ between 1.188 and 1.222. The other signature, obtained in samples collected close to the open ocean, more distant of the continent, indicates values of ${ }^{207} \mathrm{~Pb} /{ }^{206} \mathrm{~Pb}$ between 1.322 and 1.323 and can be interpreted as an oceanic source according to the [8] [9].

The comparison of these values with data of the literature of studies in coastal areas in Brazil is shown in Figure 7. In this way, the studies reported by [10] in the Sepetiba Bay (Rio de Janeiro), [11] in the Guanabara Bay (Rio de Janeiro), [12] in lagoons close to Belem (Pará) and Mahiques et al. (2008) with analysis of sediments in oceanic waters collected in the coast of Brazil and Argentina are compared in the diagram.

The lead isotope data obtained in the sediments of Sepetiba Bay by Cunha et al. (2009) are coherent with the hydrodynamic model where the pollutants are carried throughout the fluvial waters that flow into the bay. The 


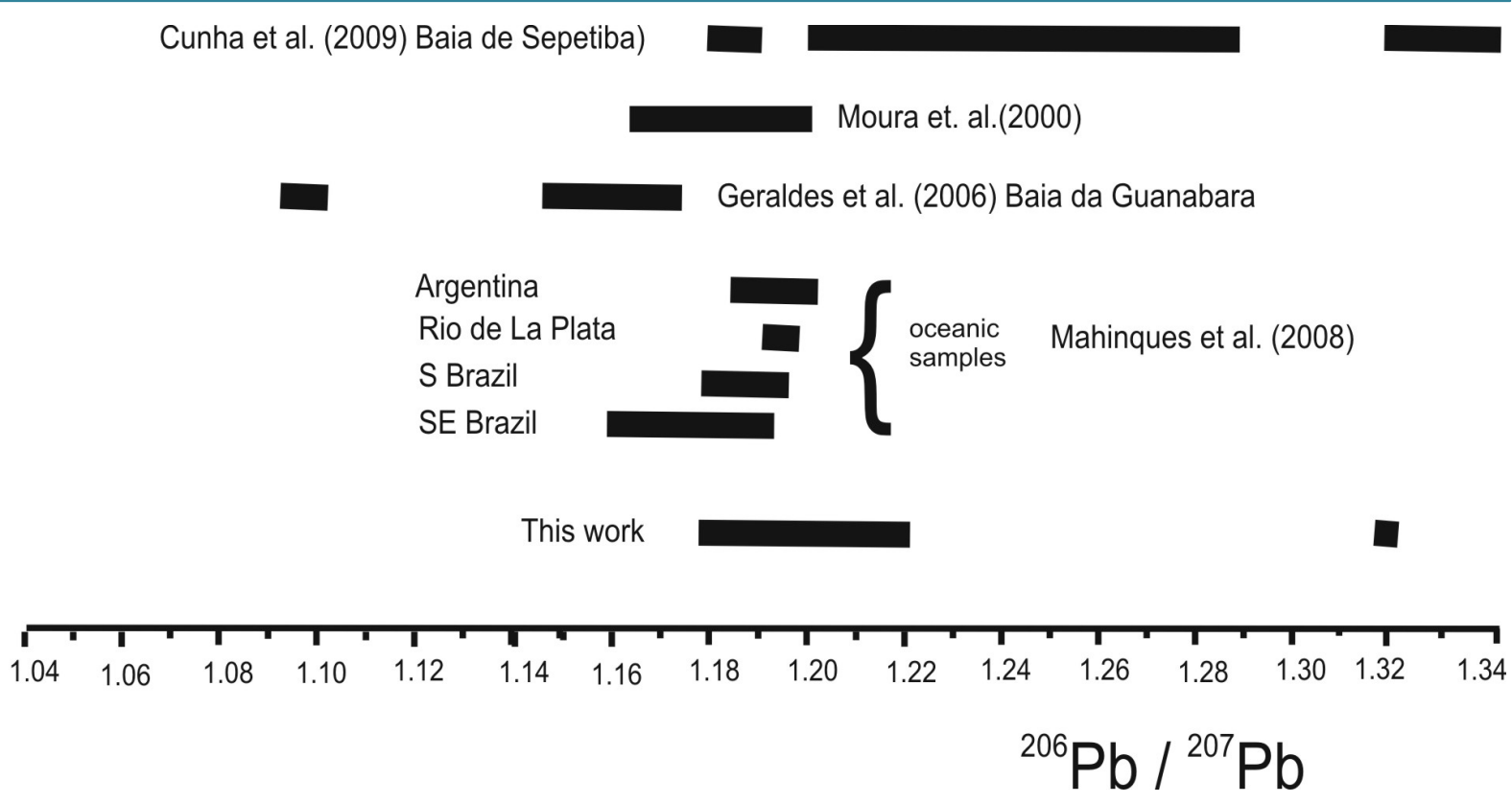

Figure 7. Comparison of the values of $\mathrm{Pb}$ isotopes here reported with values with data of the literature of studies in coastal areas in Brazil and Argentina.

authors have identified two end members: one is represented by the water of Guandu River and the second is represented by oceanic waters. Both are mixed by the currents inside the bay, in a movement with clock direction. In this case, the collected sediments next the mouth of Guandu River $\left({ }^{206} \mathrm{~Pb} /{ }^{207} \mathrm{~Pb}\right.$ between 1.188 and 1.191$)$ are similar the isotopic signature of the gasoline and industrial pollution $\left({ }^{206} \mathrm{~Pb} /{ }^{207} \mathrm{~Pb}\right.$ between 1.072 and 1.330$)$ and similar to the end member A (close to the continent) here reported. On the other hand, the collected sediments next the entrance area of the Sepetiba Bay, the oceanic water yielded values of ${ }^{206} \mathrm{~Pb} /{ }^{207} \mathrm{~Pb}$ between 1.341 and 1.336 and suggest a second source, very close to the $\mathrm{Pb}$ signature values here reported to the end member $\mathrm{B}$. If this hypothesis is correct, the signature of lead isotopes of the ore used for the industrial area in the Paraty and Pouso Bay here reported are also responsible for the pollution for metals in the area inside of Sepetiba Bay.

For the Guanabara Bay the results of the isotopic analyses reported by Geraldes et al. (2006) show that the samples collected in Paquetá Island (PQ-01, PQ-02, PQ-03, PQ-04 and PQ-05), present for the ratio ${ }^{206} \mathrm{~Pb} /{ }^{207} \mathrm{~Pb}$ values between 1.174 and 1.152. For the samples collected in Surui River (SU-06, SU-07, SU-08, SU-09 and SU-10) the values presented for the ratio ${ }^{206} \mathrm{~Pb} /{ }^{207} \mathrm{~Pb}$ are between 1.065 and 1.092. For the samples of Guanabara Bay (BG-11 and BG-12) the values presented for the ratio ${ }^{206} \mathrm{~Pb} /{ }^{207} \mathrm{~Pb}$ are of 1.155 and the 1.166. For the samples of Iriri River (IR-13, IR-14 and IR-15) the values presented for the ratio ${ }^{206} \mathrm{~Pb} /{ }^{207} \mathrm{~Pb}$ are between 1.164 and 1.156. These values can be interpreted as end members (represented for Surui and Iriri Rivers) and the values obtained in the sediments of the Guanabara Bay may represent mixture similar to the end member A here reported. Paqueta Island (within Guanabara Bay) indicates a distinct $\mathrm{Pb}$ signature probably due local pollutant.

The work of [12] reports isotopic data of $\mathrm{Pb}$ in lagoon sediments of Belem region (Pará) and includes results of $\mathrm{Pb}$ isotopes in core of $80 \mathrm{~cm}$ of length, characterizing the anthropogenic contributions result of domestic sewers. The ${ }^{206} \mathrm{~Pb} /{ }^{207} \mathrm{~Pb}$ values are similar to the end member A here reported.

According to [13], sediments from the Southern Brazil and Argentina exhibit a mixture of sediment materials from the La Plata River estuary with source areas represented by cratonic units (old crust) as suggested by the high radiogenic $\mathrm{Pb}$ isotopic values. Samples from Southern Brazil exhibit average values of ${ }^{206} \mathrm{~Pb} /{ }^{207} \mathrm{~Pb}$ from 1.178 to 1.196 , followed by sediments from the La Plata River estuary $\left({ }^{206} \mathrm{~Pb} /{ }^{207} \mathrm{~Pb}\right.$ from 1.1 .190 to 1.196$)$, Argentina ${ }^{206} \mathrm{~Pb} /{ }^{207} \mathrm{~Pb}$ from 1.183 to 1.195$)$. Samples from Southeastern Brazil show ${ }^{206} \mathrm{~Pb} /{ }^{207} \mathrm{~Pb}$ values from 1.158 to 1.193. As distinctive features we may observe the displacement of the $\mathrm{Pb}$ isotopes of the samples from S Brazil, between $27^{\circ} \mathrm{S}$ and $25^{\circ} \mathrm{S}$, towards more radiogenic values at $25^{\circ} \mathrm{S}$. The ${ }^{206} \mathrm{~Pb} /{ }^{207} \mathrm{~Pb}$ values reported by [13] are similar to the end member A here reported.

In addition, other studies characterizing the isotopic signature of $\mathrm{Pb}$ in sediments are reported in Brazil in continental areas whose results had been plotted in the diagram of Figure 8 for comparison. Among these stu- 
Aily (2001), fonte industrial

Gioia et. al. (2003), gasolina

Bollhöfer e Rosman (2000), gasolina

Moura et. al.(2000) esgoto doméstico

Geraldes et al. (2003) Baia da Guanabara

Rio São Domingos

gasolina? pesticidas?

\begin{tabular}{|c|c|c|c|c|c|c|c|c|c|c|c|c|c|}
\hline 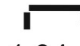 & $T$ & $\mathbf{T}$ & $T$ & $T$ & $T$ & $T$ & $\mathbf{T}$ & $T$ & $\mathbf{T}$ & T & $T$ & T & 7 \\
\hline 1.04 & 1.06 & 1.08 & 1.10 & 1.12 & 1.14 & 1.16 & 1.18 & 1.20 & 1.22 & 1.24 & 1.26 & 1.28 & 1.30 \\
\hline
\end{tabular}

Figure 8. Comparison of the values of $\mathrm{Pb}$ isotopes here reported with values of reported studies in continental areas in Brazil.

dies can be cited [1] [14]-[16]. All the works present results of isotopic composition of Pb of sediments, whole rock, K-feldspar, soils, fuels and aerosols, corresponding to isotopic signatures of rocks and environments or current deposition of sediments.

The ${ }^{206} \mathrm{~Pb} /{ }^{207} \mathrm{~Pb}$ values reported by [14] in gasoline and aerosols are similar to the values here reported. In similar way, the ${ }^{206} \mathrm{~Pb} /{ }^{207} \mathrm{~Pb}$ values obtained by [16] in gasoline and industrial waste are in the same range of the ${ }^{206} \mathrm{~Pb} /{ }^{207} \mathrm{~Pb}$ values here reported for the end member $\mathrm{A}$. Only the ${ }^{206} \mathrm{~Pb} /{ }^{207} \mathrm{~Pb}$ values reported by [15] for Neoproterozoic $\mathrm{Pb}$ ore showed different range and indicated that the ore from Vale do Ribeira mining district was not the source of the lead identified in the Paraty area.

\section{Concluding Remarks}

The results here presented from Paraty Bay showed $\mathrm{Pb}$ isotopic signatures values from 1.118 to 1.209. The $\mathrm{Pb}$ isotopic analysis of the samples collected in the Pouso Bay defined two groups: the first with values from 1.188 to 1.222 and the second with values from 1.321 to 1.323 . These results may be interpreted as two $\mathrm{Pb}$ isotope signatures comprised of continental sediments and antropic pollution and oceanic signature.

When compared with antropic sources, the results here reported are similar to the $\mathrm{Pb}$ isotope values of gasoline ${ }^{206} \mathrm{~Pb} /{ }^{207} \mathrm{~Pb}$ values about 1.2$)$ and industrial waste $\left({ }^{206} \mathrm{~Pb} /{ }^{207} \mathrm{~Pb}\right.$ values from 1.16 to 1.35$)$. The ${ }^{206} \mathrm{~Pb} /{ }^{207} \mathrm{~Pb}$ values from 1.151 to 1.091 here presented are similar to the anthropogenic signatures reported in other works in Brazil (Figure 7). For example, two studies using $\mathrm{Pb}$ isotope signatures of aerosols have been reported: the first study [1] reports aerosols Pb signatures from Brazil (9 samples), Argentina (3 samples) and Chile (9 samples) and shows ${ }^{206} \mathrm{~Pb} /{ }^{207} \mathrm{~Pb}$ values from 1.147 to 1.177 . Studies on the $\mathrm{Pb}$ isotope composition of the São Paulo city atmosphere [14] collected daily during fourteen months (August, 1999-September, 2000) indicate ${ }^{206} \mathrm{~Pb} /{ }^{207} \mathrm{~Pb}$ values from 1.142 to 1.273. The values are related to contribution of Pb-containing gasoline additives and industrial activities. $\mathrm{Pb}$ isotope studies in sediments are reported also in Brasilia (DF) and Belém (PA) where ${ }^{206} \mathrm{~Pb} /{ }^{207} \mathrm{~Pb}$ values range 1.152 and 1.202 [16] and 1.162 and 1.203 [12] and characterize anthropogenic sources which are interpreted as sewage and industrial polluters.

The $\mathrm{Pb}$ isotope results from Paraty and Pouso Bay are coherent (end member A) with the reported data from the continent mentioned above. We may conclude that significant isotopic differences in $\mathrm{Pb}$ signatures are con- 
sequence of anthropogenic $\mathrm{Pb}$ isotope variations [17] [18]. In this way, $\mathrm{Pb}$ isotope is an important tool to trace the changing sources of pollutant $\mathrm{Pb}$ (and other metals) in ocean environment through time.

\section{Acknowledgements}

This work was sponsored by FAPERJ Grant E-26/100.662/2009 to M.C.G. and CNPq Grant 552904/2007-4 to S.D.P.

\section{References}

[1] Bollhöfer, A. and Rosman, K.J.R. (2000) Isotopic Source Signatures for Atmospheric Lead: The Southern Hemisphere. Geochimica et Cosmochimita Acta, 64, 3251-3262. http://dx.doi.org/10.1016/S0016-7037(00)00436-1

[2] Marcantonio, F., Zimmerman, A., Xu, Y.F. and Canuel, E. (2002) A Pb Isotope Record of Mid-Atlantic US Atmosphere Pb Emissions in Chesapeake Bay Sediments. Marine Chemistry, 77, 123-132. http://dx.doi.org/10.1016/S0304-4203(01)00081-0

[3] Hong, S., Candelone, J.P. and Boutrons, C.F. (1994) Greenland Ice Evidence of Hemisphere Scale Pollution for Lead Two Millennia Ago by Greek and Roman Civilizations. Science, 265, 1841-1843. http://dx.doi.org/10.1126/science.265.5180.1841

[4] Luck, J.M. and Othman, D.B. (2002) Trace Elements and Pb Isotope Variability during Rainy Events in the NW Mediterranean: Constraints on Anthropogenic and Natural Sources. Chemical Geology, 182, 443-460. http://dx.doi.org/10.1016/S0009-2541(01)00324-2

[5] Paula, A.H. and Geraldes, M.C. (2005) Holocene Pb Isotope Chronological Standard Curve: The Record of the Anthropogenic Activity in the Last 6,000 Years. Terrae, 2, 55-60

[6] Niagru, J.O. (1989) A Global Assessment of Natural Sources of Atmospheric Trace Metal. Nature, 338, 47-49. http://dx.doi.org/10.1038/338047a0

[7] Verón, A., Flament, P., Bertho, M.L., Alleman, L., Flegal, R. and Hamelin, B. (1999) Isotopic Evidence of Pollutant Lead Sources in Northwestern France. Atmospheric Environment, 33, 3377-3388. http://dx.doi.org/10.1016/S1352-2310(98)00376-8

[8] Stevenson, M.R., Dias-Brito, D., Stech, J.L. and Kampel, M. (1998) How Do Cold Water Biota Arrive in a Tropical Bay near Rio de Janeiro, Brazil? Continental Shelf Research, 18, 1595-1612. http://dx.doi.org/10.1016/S0278-4343(98)00029-6

[9] Miranda, L.B., Ikeda, Y., Castro-Filho, B.M. and Pereira-Filho, N. (1977) Note on the Occurrence of Saline Fronts in the Ilha Grande (RJ) Region. Boletim do Instituto Oceanográfico, 26, 249-256. http://dx.doi.org/10.1590/S0373-55241977000200003

[10] Cunha, B.C.A., Rocha, D., Geraldes, M.C., Pereira, S.D. and Almeida, A.C. (2009) Pb Isotopic Signatures in Sediments of a Sub-Tropical Coastal Lagoon: Anthropogenic Sources for Metal Contamination in the Sepetiba Bay (SEBrazil). Journal of Coastal Research, 56, 797-801.

[11] Geraldes, M.C., Paula, A.H., Godoy, J.M. and Valeriano, C.M. (2006) Pb Isotope Signatures of Sediments from Guanabara Bay, SE Brazil: Evidence for Multiple Anthropogenic Sources. Journal of Geochemical Exploration, 88, 384387. http://dx.doi.org/10.1016/j.gexplo.2005.08.081

[12] Moura, C.A.V., Gaudette, H.E., Carvalho, M.C. and Morales, G.P. (2004) The Use of Lead Isotope Composition as a Tool to Investigate the Anthropogenic Impacts on the Environment in the Metropolitan Region of Belém (PA). Terrae, 1, 16-25.

[13] Mahiques, M.M., Tassinari, C.C.G., Marcolinic, S., Violantec, R.A., Figueira, R.C.L., Silveira, I.C.A., Buronea, L. and de Mello e Sousa, S.H. (2008) Nd and Pb Isotope Signatures on the Southeastern South American Upper Margin: Implications for Sediment Transport and Source Rocks. Marine Geology, 250, 51-63. http://dx.doi.org/10.1016/j.margeo.2007.11.007

[14] Aily, C. (2002) Caracterização isotópica de Pb na atmosfera: Um exemplo da cidade de São Paulo. Dissertação de mestrado, Instituto de Geociências, USP, São Paulo, 76 p.

[15] Moraes, R.P., Figueiredo, B.R. and Lafon, J.M. (2004) Pb-Isotopic Tracing of Metal-Pollution Sources in the Ribeira Valley, Southeastern Brazil. Terrae, 1, A19-A26.

[16] Gioia, S.M.C.L., Pimentel, M.M., Guimarães, E.M., Campos, J.E.L., Dantas, E.L. and Maruoka, M.T.S. (2003) Atmospheric Deposition and Sources of Anthropogenic Lead in Sediments from an Artificial Lake in Brasilia, Central Brazil. Proceedings of the IV South American Symposium on Isotope Geology, Salvador-Bahia, 24-27 August 2003, 434-437. 
[17] Helland, A., Göran, A. and Skei, J. (2002) Source Dependent Behavior of Lead and Organic Matter in the Glomma Estuary, SE Norway: Evidence from Isotope Ratios. Marine Chemistry, 78, 149-169. http://dx.doi.org/10.1016/S0304-4203(02)00016-6

[18] Komárek, M., Ettler, V., Chrastný, V. and Mihaljevič, M. (2008) Lead Isotopes in Environmental Sciences: A Review. Environment International, 34, 562-577. 